\title{
Material Clause Re-contextualization in Indonesian-English Translation
}

\author{
Made Susini \\ Warmadewa University, Bali, Indonesia \\ I Nengah Sudipa \\ Udayana University, Bali, Indonesia \\ I Nyoman Suparwa \\ Udayana University, Bali, Indonesia \\ Ida Ayu Made Puspani \\ Udayana University, Bali, Indonesia
}

\begin{abstract}
This research is to investigate linguistic re-contextualization found in the translation from Indonesian into English. Applying pragmatic translation equivalence (House, 2015) and Systemic Functional Linguistics (Halliday and Matthiessen, 2014), it focuses on how material clause in Indonesian meditation text is rendered into English. The research finding shows that to achieve translation equivalence, Indonesian material clause is re-contextualized by rendering it into relational clause of attributive, relational clause of identification and material clause using different type of process. The re-contextualization results in shift of dematerialization and shift from one type of material clause into another type of material clause.
\end{abstract}

Index Terms - material clause, re-contextualization, translation equivalence, transitivity shift

\section{INTRODUCTION}

Indonesian and English are languages which have different language system and culture. When these languages are involved in translation, linguistic re-contextualization is needed and this becomes a common phenomenon in the translations from Indonesian into English, or vice versa. Such a translation adjustment can be found in numerous Indonesian texts which have been translated into English, including text of meditation. Meditation text is categorized as operative text since the orientation of this text is to persuade readers or receivers to act in a certain way (Reiss, 1989).

This present study deals with the translation of meditation text from Indonesian into English. To convey meaning, the source language (SL) uses some types of clause. One of the clause types used is material clause. This research is to explore how material clause is re-contextualized due to the difference of culture between Indonesian and English. In Systemic Functional Linguistics (SFL) proposed by Halliday and Matthiessen (2014), there are six types of clause which include material, verbal, mental, behavioral, relational and existential clause. These clause types are as the grammatical realizations to represent the experience of the world and how meaning is conveyed can be examined from their transitivity structures. The transitivity structure of every clause consists of three components which include participant, process and circumstance. When the process is filled with process of material, the clause is categorized as material clause. Material process is a process of doing and happening (Halliday and Matthiessen, 2014, p. 224).

Material clause used in Indonesian text of meditation is not always rendered into the same clause type in English. How this clause is rendered into English depends on some factors, such as the orientation of the translation, the ideology of the translator and the translation strategies applied. Considering that changes in translation are the translator's decision, shifts of transitivity structure are also unavoidable. Material clause in Indonesian text is possibly rendered into other types of clause in English and this phenomenon becomes interesting to be examined.

Studies on translation have been conducted by a number of researchers. They evaluated translation from different perspectives, such as Huang (2015) and Mohammed (2019) who worked on translation strategies and Wang (2015) on translation equivalence. As long as the subject of research is concerned, their works did not deal with the translation of meditation text, especially on how Indonesian material clause is re-contextualized in English. Drawing pragmatic equivalence (House, 2015)) and Systemic Functional Linguistics (Halliday and Matthiessen, 2014), this research is conducted to answer the questions as follows:

a. What types of material clause are found in Indonesian text of meditation?

b. How are they rendered into English?

\section{THEORETICAL FRAMEWORK}


Translation study on meditation text from Indonesian into English concerns with linguistic and cultural differences of the two languages. Linguistic constructions used to realize meaning in the source language (SL) and in the target language (TL) are very much influenced by the context of situation and context of culture. Considering that the result of the translation is influenced by context, this present study applied theories of translation and theories on how language is used in a certain context. The theories applied are Systemic Functional Linguistics (SFL) (Halliday and Matthiessen, 2014) and pragmatic translation theory (House, 2015).

\section{A. SFL: Transitivity Structure}

Translation concerns with language in use. The linguistic form used as the translation equivalent in TL must be viewed as a text. Since translation concerns with language as a text, translation studies need functional theory. SFL (Halliday and Matthiessen, 2014) is a theory which concerns with the use of language in context. Based on this theory, the language people use must be in accordance with the function of the language it conveys. The language can be used to share experience of the world which deals with ideational meaning, to create personal relation which deals with interpersonal meaning or to make textual chain which deals with textual meaning.

The ideational function of a language is realized by transitivity structure in the form of a clause. A clause consists of three components which include process, participant and circumstance. Process is categorized as process of material, mental, verbal, behavioral, relational and existential. Based on the type of process used in a clause, clause is categorized into clause of material, mental, verbal, behavioral, relational and existential.

\section{B. Re-contextualization in Translation}

Viewing translation as intercultural communication, translation equivalence of House (2015) is based on the concept of interconnectedness between context and text. Text used as the equivalent of the SL text must be evaluated from its context. By this concept, preserving meaning in TT includes the three aspects of meaning: semantic meaning, pragmatic meaning and textual meaning (House, 2015, p. 21). To evaluate the quality of translation, House (2015) proposed a model of register analysis (p. 127).

Register analysis model is based on text-context and equivalence is the fundamental criterion of translation quality. The SL and TL texts are analyzed from their register dimensions which include dimensions of Field, Tenor and Mode. Field is realized in transitivity structure and in what transitivity structure meaning is realized is different between languages. When there is difference in realizing meaning between SL and TL, the SL text needs to be re-contextualized that shifts of transitivity may occur in TL. The type of shifts which occur depends on the changes of the process used, such as dematerialization, materialization, expansion, contraction and some others (Pérez, 2007, p. 152). To what types of transitivity structure the SL text is re-contextualized is also influenced by the translation strategies applied. A number of translation strategy can be applied, among those are strategy of equation, substitution, convergence, divergence, amplification, reduction, diffusion, condensation and reordering (Malone, 1988).

\section{RESEARCH METHOD}

This study used a book of meditation entitled Butir-Butir Kebijaksanaan: Titian Hidup Sehat dengan Meditasi BioEnergi Ratu Bagus (Ida Pandita Mpu Nabe Parama Daksa Natha Ratu Bagus, 2012) as SL texts and its translation in English entitled Pearls of Wisdom: The Path of a Healthy Life with Ratu Bagus Bio-Energy Meditation (Stacey, 2014) as TL texts. Descriptive qualitative approach was employed and the stages carried out were as the followings.

The clauses composing the source text were examined by applying functional grammatical analysis. The constituents of the clause were analyzed to identify the type of process used. When the process of the clause is filled with process of material, the clause is categorized as material clause. All material clauses found were classified based on their types, such as material clause of action, event, operative or receptive.

The source material clauses were then compared with their TL texts to investigate in what types of clause the target texts were realized. When the target texts have different transitivity structure, this is identified as the result of linguistic re-contextualization in the translation under study. The next step was identifying the type of translation shifts found (Pérez, 2007). The analysis was also completed with the analysis on the translation strategies applied which lead to the shifts (Malone, 1988).

\section{RESULT AND DiSCUSSION}

The result shows that to achieve translation equivalence, some types of Indonesian material clauses used in meditation text are re-contextualized in TL. They are rendered into other types of clause which include relational clause and material clause. Re-contextualization results in shifts of transitivity and the shifts which occur depend on the strategies applied. The changes of Indonesian material clause when translated into English are summarized as the followings. 
TABLE I

INDONESIAN MATERIAL CLAUSE RE-CONTEXTUALIZATION

\begin{tabular}{|c|c|c|c|c|}
\hline SL clause types & Translation strategies & Transitivity shifts & & TL clause types \\
\hline \multirow{3}{*}{ Mat/Event } & \multirow{3}{*}{ diffusion } & \multirow{3}{*}{ dematerialisasi } & - & Rel/Attributive/Possessive \\
\hline & & & - & Rel/Attributive \\
\hline & & & - & Rel/Attributive/Attributor \\
\hline Mat/Event & equation & dematerialisasi & - & Rel/Attributive/Possesive \\
\hline Mat/Event & reordering & Mat $\rightarrow$ Mat & - & Mat/Action/operative \\
\hline \multirow{3}{*}{ Mat/Action/operative } & \multirow{3}{*}{ diffusion } & \multirow{3}{*}{ dematerialisasi } & - & Rel/Attributive \\
\hline & & & - & Rel/Attributive/Possessive \\
\hline & & & - & Rel/Identification \\
\hline Mat/Action/operative & reordering & Mat $\rightarrow$ Mat & - & Mat/Event/operative \\
\hline \multirow{2}{*}{ Mat/Action/receptive } & \multirow{2}{*}{ diffusion } & \multirow{2}{*}{ dematerialisasi } & - & Rel/Attributive \\
\hline & & & - & Rel/Attributive/Attributor \\
\hline \multirow{2}{*}{ Mat/Action/receptive } & reordering & Mat $\rightarrow$ Mat & - & Mat/Action/operative \\
\hline & equation & Mat $\rightarrow$ Mat & - & Mat/Event/operative \\
\hline
\end{tabular}

\section{A. Material Clause of Event Rendered into Relational Clause}

Material clause of event is re-contextualized in TL by rendering it into relational clause/Attributive, relational clause/Attributive/possessive and relational clause/Attributive with Attributor. The data are presented in the following completed with their transitivity structures.

(1) SL: Tetapi jika badan digerakkan oleh pikiran, kita akan selalu meminta. Janganlah berjiwa kerdil. Pelajarilah kehidupan dan luaskan jiwa kita. Hidup ini akan damai jika dunia ini dipenuhi oleh jiwa-jiwa besar (p. 163).

TL: $\quad$...; but if we are coming from the mind, we will always take. Let's not be petty minded. Let's learn about life and expand our Soul. This life will be peaceful if the world is full of big Souls (p. 163).

\begin{tabular}{|c|c|c|c|c|c|}
\hline \multirow{2}{*}{ SL } & jika & dunia ini & \multicolumn{2}{|l|}{ dipenuhi } & oleh jiwa-jiwa besar \\
\hline & & Goal & \multicolumn{2}{|l|}{ Pro: Mat/Event/recep } & Actor \\
\hline \multirow{2}{*}{ TL } & if & the world & is & full & of big Souls \\
\hline & & Carrier & Pro: Rel/Attrib & Attribute & Circums \\
\hline
\end{tabular}

The transitivity structures of the source and target texts show that the SL text is in the form of material clause of event/receptive filled with Process 'dipenuhi', Actor 'dunia ini' and Goal 'jiwa-jiwa besar'. The TL text is in the form of relational clause. The process used is relational process 'is'. This process is completed with component Carrier 'the world' and Attribute 'full'. Shift of dematerialization occurs in this translation since the process changes from material process into relational process. In this translation, one component of the SL clause is rendered into a form filling two components. The component of Process filled with 'dipenuhi' is rendered into the components of Process and Attribute filled with 'is full'. This means that the strategy applied is the strategy of diffusion since the TL text uses more expansively text construction to realize the SL meaning.

(2) SL: Pranāyama yang dilakukan dengan maximal akan memberikan dampak kesehatan, karakter, dan spiritual. Segala hal yang sifatnya negatif bisa dihilangkan (p. 32).

TL: Pranayama, when practiced with maximum concentration, has an impact on heart, character and spirituality. All negative characteristics can be cleared (p. 32).

\begin{tabular}{|l|l|l|l|}
\hline \multirow{3}{*}{ SL } & $\begin{array}{l}\text { Pranāyama yang dilakukan dengan } \\
\text { maximal }\end{array}$ & akan memberikan & $\begin{array}{l}\text { dampak kesehatan, karakter, dan } \\
\text { spiritual }\end{array}$ \\
\cline { 2 - 4 } & Actor & Pro: Mat/Event & Goal \\
\hline \multirow{2}{*}{ TL } & \begin{tabular}{l} 
Pranayama when practiced with maximum \\
concentration \\
\cline { 2 - 4 }
\end{tabular} & has & $\begin{array}{l}\text { an impact on heart, character and } \\
\text { spirituality }\end{array}$ \\
\hline
\end{tabular}

The source text in this translation is filled with process of material/event. The process of the clause is represented by verb 'akan memberikan'. The Actor is inanimate participant represented by 'Pranāyama yang dilakukan dengan maximal' and the Goal by 'dampak kesehatan, karakter, dan spiritual'. The target text is in relational clause of attributive/possessive. Its process is filled with verb 'has'. In this translation, material clause of event/operative is rendered into relational clause of attributive/possessive. The type of shift which occurs is dematerialization. Material clause becomes non-material clause in TL. One component in SL filled with process of material 'akan memberikan' is directly rendered into one component in TL filled with relational process 'has'. This indicates that the strategy of equation is applied to achieve the translation equivalence.

\section{B. Material Clause of Event/Operative Rendered into Material Clause of Action/Operative}

In some cases, the SL material clause of event becomes material clause of action/operative in TL. 
(3) SL: Hidup kita mesti selalu bermain dengan jiwa, sebab secara otomatis sifat-sifat satwik kita akan tumbuh. Organ tubuh kita akan memberikan yang terbaik untuk kita sepanjang tubuh tersebut tidak tertekan (p. 117).

TL: Our life has to be a constant play with the Soul; we then automatically develop a satwik character [a person of good character]. Our physical organs will give us the best when the body is not under stress (p. 117).

\begin{tabular}{|c|c|c|c|c|}
\hline \multirow{2}{*}{ SL } & \multicolumn{2}{|c|}{ secara otomatis } & sifat-sifat satwik kita & akan tumbuh \\
\hline & \multicolumn{2}{|c|}{ Circums } & Actor & Pro: Mat/Event/operat \\
\hline \multirow{2}{*}{ TL } & we & then authomatically & develop & a satwik character \\
\hline & Actor & Circums & Pro: Mat/Act/operat & Goal \\
\hline
\end{tabular}

The source text in the translation above is in the form of clause of material/event/operative. Actor is filled with inanimate participant represented by 'sifat-sifat satwik kita'. This clause is re-contextualized in TT becoming clause of material/action/operative. Re-contextualization in this translation results in a shift from material clause of event/operative into material clause of action/operative. The TL Actor is filled with animate participant and there is a change of position of the clause components. The SL Actor becomes TL Goal in this translation. This change of function also indicates that the shift which occurs in this translation is caused by the strategy of reordering.

(4) SL: Melalui password 'Om Swastyastu Ratu Bagus' blok yang menutupi pikiran kita akan hancur. Getaran yang dimunculkan dari latihan shaking bagi seluruh tubuh akan membangkitkan energi yang ada (p. 88).

TL: With the password Om Swastyastu Ratu Bagus we can break through the block that closes our mind. When we shake, the vibration that travels through the entire body wakes up our innate Energy (p. 87).

\begin{tabular}{|l|l|l|l|l|}
\hline \multirow{3}{*}{ SL } & $\begin{array}{l}\text { Melalui password 'Om Swastyastu Ratu } \\
\text { Bagus }\end{array}$ & $\begin{array}{l}\text { blok yang menutupi pikiran kita } \\
\text { akan }\end{array}$ & akan hancur \\
\cline { 2 - 5 } & Circums & Actor & Pro: Mat/Event/operat \\
\hline \multirow{2}{*}{ TL } & $\begin{array}{l}\text { With the password Om Swastyastu Ratu } \\
\text { Bagus }\end{array}$ & we & can break through & $\begin{array}{l}\text { the block that closes our } \\
\text { mind }\end{array}$ \\
\cline { 2 - 4 } & Circums & Actor & Pro: Mat/Act/operat & Goal \\
\hline
\end{tabular}

The transitivity structures of the SL and TL texts show that the material clause of event/operative of the SL is recontextualized in TL. The clause type of the SL text changes in TL. The TL text is filled with material clause of another type. That is material clause of action/operative. The shift is only from one type of material clause to another type of the same process. Although this translation contains such kind of shift, there is a kind of a change in the position of the clause component. The SL text functioning as Actor becomes Goal in TL. This shows that there is strategy of reordering in this translation.

\section{Material Clause of Action/Operative Rendered into Relational Clause}

Material clause of action is also re-contextualized into relational clause. The following is the SL material clause of action/operative which is rendered into relational clause of identification.

(5) SL: Kita mesti ada di dalam frekwensi energi yang lebih tinggi, sebab jika tidak di dalam frekuensi itu, energi tidak mungkin bisa berdaya guna bagi kita. Oleh karena itu, mari kita berguru pada jiwa, sebab jiwa akan membimbing kita ke arah frekuensi tersebut (p. 114).

TL: We have to be in the higher frequency of Energy, because if we don't, Energy is of no use to us. Let therefore the Soul be our teacher because the Soul can take us to this frequency (p. 115).

\begin{tabular}{|l|l|l|l|l|l|}
\hline \multirow{2}{*}{ SL } & Oleh karena itu & mari & kita & berguru & pada jiwa \\
\cline { 2 - 6 } & Pro- & Actor & -cess: Mat/Act/operat & Circums \\
\hline \multirow{2}{*}{ TL } & Let & the Soul & be & our teacher \\
\cline { 2 - 5 } & Pro- & Token & -cess/ Rel/Ident & Value \\
\hline
\end{tabular}

The re-contextualization in the translation above can be examined from the transitivity structures of the SL and TL texts. The SL text uses process of material/action/operative represented by verb 'berguru', while the TL is filled with process of relational represented by verb 'be'. Shift of dematerialization occurs in this translation. That is there is a change from material process into non-material process. This kind of shift in this translation is caused by the strategy applied. To express the SL meaning of 'berguru' which is realized in one component, the TL uses two components. They are component of Process filled with 'be' and of Value filled with 'our teacher'. This kind of strategy belongs to strategy of diffusion.

\section{Material Clause of Action/Operative Rendered into Material Clause of Event/Operative}

The translation of meditation text from Indonesian into English also shows that clause of material/action/operative can be rendered into clause of material/event/operative to achieve equivalence. 
(6) SL: Kemurnian ini akan cukup untuk kita di dalam persiapan untuk menghadapi kematian. Ketika energi kita getarkan setiap saat di dalam tubuh kita, maka jalan Tuhan semakin terang di depan mata kita. Energi adalah gerbang menuju Tuhan (p. 2).

TL: This purification is sufficient to prepare ourselves for the moment of death. When our Energy vibrates constantly in our body, we can see our path towards God ever more clearly. Energy is the gateway that leads to God (p. 2).

\begin{tabular}{|c|c|c|c|c|c|}
\hline \multirow{2}{*}{ SL } & Ketika & energi & kita & getarkan & setiap saat di dalam tubuh kita \\
\hline & & Goal & Actor & Pro: Mat/Act/operat & Circums. \\
\hline \multirow{2}{*}{$\mathrm{TL}$} & When & \multicolumn{2}{|c|}{ our Energy } & vibrates & constantly in our body \\
\hline & & \multicolumn{2}{|l|}{ Actor } & Pro: Mat/Event/operat & Circums \\
\hline
\end{tabular}

The material clause of the SL is filled with process material/action/operative represented by verb 'getarkan'. The clause comes with obligatory components which include Actor represented by ' $k i t a$ ' and Goal by 'energi'. In its translation the clause is re-contextualized becoming material clause of event/operative. Actor is filled with inanimate participant and Process is filled with material process of event represented by 'vibrates'. The shift is only from one kind of material process to another type of material clause. In this translation the element filling the function of Goal in SL becomes Actor in TL. There is a change of position. This indicates that the translator applied strategy of reordering to make an adequate translation.

(7) SL: Energi tidak bisa dikuasai oleh pikiran. Energi hanya bisa diraih melalui pikiran. Dengan energy, kita bisa merubah fisik, emosi, dan mental (p. 163).

TL: Energy cannot be controlled by the mind. It can only be attained by the Soul. Energy can change us physically, emotionally and mentally (p. 163).

\begin{tabular}{|l|l|l|l|l|}
\hline \multirow{2}{*}{ SL } & Dengan energi & kita & bisa merubah & fisik, emosi, dan mental \\
\cline { 2 - 5 } & Circums & Actor & Pro: Mat/Act/operat & Goal \\
\hline \multirow{2}{*}{ TL } & Energy & can change & us & phsically, emotionally and mentally \\
\cline { 2 - 5 } & Actor & Pro: Mat/Event/operat & Goal & Circums \\
\hline
\end{tabular}

The transitivity structure of the translation above also shows that material clause of action/operative is rendered into material clause of event/operative. The shift which occurs is only from one type of material process to another type. Because of the shift, there is a change of function. The element of SL functioning as Circumstance changes into the function of Actor in TL. This change shows that the translation strategy applied is strategy of reordering.

\section{E. Material Clause of Action/Receptive Rendered into Relational Clause of Attributive}

Material clause of action/receptive can turn into relational clause of attributive and relational clause of attributive with attributor. The following is the representative of the data found.

(8) SL: Tuhan tidak bisa didekati dengan konsep. Hanya kepolosan yang mampu mengetuk hati Tuhan (p. 26).

TL: We cannot get close to God with theories. Only pure innocence can open the door to God's heart (p. 27).

\begin{tabular}{|l|l|l|l|l|l|}
\hline \multirow{2}{*}{ SL } & Tuhan & \multicolumn{1}{l|}{ tidak bisa didekati } & \multicolumn{2}{l|}{ dengan konsep } \\
\cline { 2 - 6 } & Goal & Pro: Mat/Act/recep & \multicolumn{2}{l|}{ Circums } \\
\hline \multirow{2}{*}{ TL } & we & cannot get & close & to God & with theories \\
\cline { 2 - 4 } & Carrier & Pro: Rel/Attrib & Circums & Circums \\
\hline
\end{tabular}

The SL text in the translation above is filled with material process of action/receptive. The process does not come with the doer of the action. In its translation, the doer of the action comes in the function as Carrier because the process used by the translator to realize the same meaning is process of relational/attributive. Shift of dematerialization takes place in this translation. That is material process turns into relational process. The translator applied the strategy of diffusion since one component of process in SL represented by 'tidak bisa didekati' is rendered into two components in TL. They are components of Process relational represented by 'cannot get' and Attribute represented by 'close'.

\section{F. Material Clause of Action/Receptive Rendered into Material Clause of Another Type}

Material clause of action/receptive is re-contextualized becoming material clause of action/operative and event/operative in TL.

(9) SL: Jika kebahagiaan bisa diraih, kaya atau miskin telah tidak memiliki signifikasi sama sekali (p. 93).

TL: $\quad$ Once we reach the state of happiness, being rich or poor doen't matter anymore (p. 93). 


\begin{tabular}{|c|c|c|c|c|}
\hline \multirow{2}{*}{ SL } & Jika & \multicolumn{2}{|c|}{ kebahagiaan } & bisa diraih \\
\hline & & Goal & \multicolumn{2}{|c|}{ Pro: Mat/Act/recep } \\
\hline \multirow{2}{*}{ TL } & Once & we & reach & the state of happiness \\
\hline & & Actor & Pro: Mat/Act/operat & Goal \\
\hline
\end{tabular}

In the translation above material clause of action/receptive in SL is rendered into material clause of action/operative. The shift is from one type of material clause to another type of material clause. In SL the Actor comes after Process and Goal before Process, while in TL Actor comes before Process and Goal after Process. Change of position takes place. This indicates that the strategy applied is the strategy of reordering.

(10) SL: Kita di Ashram selalu dilatih untuk tetap berada di dalam suasana kerja keras. Latihan yang kita lakukan adalah bentuk doa kita yang efektif (p. 168).

TL: At the Ashram we are always training in an atmosphere of intensity. Our training is an effective kind of prayer (p. 169).

\begin{tabular}{|l|l|l|l|l|l|}
\hline \multirow{2}{*}{ SL } & Kita & di Ashram & selalu & dilatih & untuk tetap berada di dalam suasan kerja keras \\
\cline { 2 - 5 } & Goal & Circums & Circums & Pro: Mat/Act/recep & Circums \\
\hline
\end{tabular}

\begin{tabular}{|l|l|l|l|l|l|l|}
\hline \multirow{2}{*}{ TL } & At the Ashram & we & are & always & training & in an atmosphere of intensity \\
\cline { 2 - 7 } & Circums & Actor & Pro: & Circums & Mat/Act/operat & Circums \\
\hline
\end{tabular}

The transitivity structures of the translation above also show that the SL text is in the form of material clause using process of material/action/receptive represented by verb 'dilatih'. The TL is in the form of material clause using material process of action/operative represented by verb 'are training'. The strategy applied is also strategy of reordering since there is change in component position.

(11) SL: Upaya untuk mencari kebenaran harus diawali dengan rasa toleransi dengan yang lain. Kalau blok hidup kita dilenyapkan, maka kita akan lebih mudah menerima orang lain (p. 48).

TL: The quest for truth has to come from a feeling of tolerance towards others. When the block in our life disappears we will more easily be able to accommodate other people (p. 49).

\begin{tabular}{|c|c|c|c|}
\hline \multirow{2}{*}{ SL } & Kalau & blok hidup kita & dilenyapkan \\
\hline & & Goal & Pro: Mat/Act/recep \\
\hline \multirow{2}{*}{$\mathrm{TL}$} & When & the block in our life & disappears \\
\hline & & Actor & Pro: Mat/Event \\
\hline
\end{tabular}

There is also linguistic re-contextualization in this translation. Material clause of action/receptive in SL is rendered into material clause of event in TL. The SL process is filled with process material/action/receptive. The verb used is 'dilenyapkan'. In TL the process used is material process of event using verb 'disappears'. The shift which occurs is between material processes. In this translation the SL process of material/action/receptive is directly changed into process of material/event. So, the strategy applied is strategy of equation.

(12) SL: Untuk menghilangkan rasa takut, maka pikiran harus dihentikan bekerja. Di sinilah pentingnya kita selalu melakukan aktivitas yang melepaskan kegiatan pikiran (p. 69).

TL: To lose the fear the mind has to stop working. That's why it is important to keep doing things that stop the mind from working (p. 69).

\begin{tabular}{|l|l|l|l|l|}
\hline \multirow{2}{*}{ SL } & Untuk menghilangkan rasa takut & maka & pikiran & harus dihentikan bekerja \\
\cline { 2 - 5 } & Circums & & Goal & Pro: Mat/Act/recep \\
\hline \multirow{2}{*}{ TL } & To lose the fear & the mind & has to stop working \\
\cline { 2 - 4 } & Circums & Actor & Pro: Mat/Event \\
\hline
\end{tabular}

The transitivity structures of the translation above show that material clause of the SL is re-contextualized in TL. Material clause of action/receptive using material process of 'harus dihentikan' is rendered into material clause of event using material process of 'has to stop working'. The shift which occurs is also from material clause into material clause. Strategy of equation was applied by the translator. The receptive material process was directly translated into active material process and no position of the component changed.

To sum up, linguistic re-contextualization becomes important to be concerned when translating meditation text from Indonesian into English. Indonesian and English are languages which have different systems and characteristics. The translations presented above show that to bridge the cultural difference between Indonesian and English, some of Indonesian material clauses are re-contextualized to achieve translation equivalence. Material clauses which change in the translation are mostly rendered into relational clause and material clause of another type. The change of transitivity structure in TL results in shifts of dematerialization and shift from one type of material clause into material clause of another type.

As long as the semantic meaning can be kept constant in TL, shifts of transitivity are a common phenomenon in 
translation. The types of shift which occur depend on the translation strategies applied. But, it is worth noting that the change of transitivity structure implies that there is the change of linguistic realization and different linguistic realization in TL impacts the contextual meaning of the TT. The message which is conveyed by using process of material has different contextual meaning if it is compared with the message which is conveyed by relational clause.

SL: Oleh karena itu, mari kita berguru pada jiwa.

TL: Let therefore the Soul be our teacher.

When the message is expressed by using material clause using material process 'berguru', the message conveyed sounds more dynamic. The speaker persuades the readers or receivers to act by doing an action as represented by process 'berguru'. The message becomes more categorical in its translation because it is rendered into relational clause of identification using relational process of 'be'. The speaker does not convey the message in direct way. Change of contextual meaning also occurs when material clause of action/operative is rendered into material clause of event.

SL: Dengan energi kita bisa merubah fisik, emosi, dan mental.

TL: Energy can change us physically, emotionally, and mentally.

The message conveyed in SL is more dynamic than TL. Material process of action in SL implies that the speaker persuades the readers or receivers to act as represented by the verb 'merubah'. In TL, the Actor is filled with inanimate participant. The speaker does not invite the readers to act. It is simply to inform that it is Energy which can change us physically, emotionally, and mentally.

\section{CONCLUSION}

Indonesian material clauses can be rendered into other types of clause in English. The re-contextualization includes the change from material clause into relational clause of attributive, relational clause of identification, and material clause of another type. Material clause re-contextualization involves transitivity shift of dematerialization and shift from one type of material clause into another type of material clause. Linguistic re-contextualization in Indonesian-English translation impacts the contextual meaning of the English text.

\section{ACKNOWLEDGMENTS}

The authors wish to thank Prof. Dr. Drs Jufrizal, M.Hum. for his constructive guidance.

\section{REFERENCES}

[1] Baker, M. (2001). Encyclopedia of Translation Studies. New York: Routledge.

[2] Halliday, M.A.K. \& C.M.I.M. Matthiessen. (2014). Halliday's Introduction to Functional Grammar. Fourth Edition. New York: Routledge.

[3] House, J. (2015). Translation Quality Assessment. New York: Routledge.

[4] Huang, J. (2015). Strategies for Translating Household Appliance Instructions from Chinese to English. Theory and Practice of Language Studies, Vol. 5, No. 12, pp. 2522-2527. ISSN 1799-2591. DOI: http://dx.doi.org/10.17507/tpls.0512.12.

[5] Ida Pandita Mpu Nabe Parama Daksa Natha Ratu Bagus. (2012). Butir-Butir Kebijaksanaan: Titian Hidup Sehat dengan Meditasi Bio-Energi Ratu Bagus. ISBN 978-602-18646-0-9. Karangasem: Ashram Ratu Bagus.

[6] Malone, J.L. (1988). The Science of Linguistics in the Art of Translation. Albany: State University of New York Pess.

[7] Mohammed, A.A., M.B. Ahmed \& D.A. Abdullah. (2019). A Pragma-stylistic-assessment of Three Translations of the Meanings of Surratt Fatir into English. Theory and Practice of Language Studies, Vol. 9, No. 1, pp. 18-27. ISSN $1799-2591$. DOI: http://dx.doi.org/10.17507/tpls.0901.03.

[8] Pérez, M.C. (2007). Transitivity in Translating. Bern: Peterlang AG, International Academic Publisher.

[9] Stacey, M. (2014). Pearls of Wisdom: The Path of a Healthy Life with Ratu Bagus Bio-Energy Meditation. ISBN 978-60218646-6-1. Karangasem: Ratu Bagus Ashram.

[10] Wang, J., J. Bao, Y. Liu \& Y. Meng. (2015). A Study of English Translation of Yili Products' Advertisements from Perspective of Pragmatic Equivalence. Theory and Practice of Language Studies. Vol. 5, No. 5, pp. 1072-1077. ISSN 1799-2591. DOI: http://dx.doi.org/10.17507/tpls.0505.23.

Made Susini was born in Singaraja, Bali, Indonesia. She is a lecturer in English Department, Faculty of Letters, Warmadewa University, Bali, Indonesia. She obtained her Master Degree in Applied Linguistics (Translation) in 2005 from Udayana University, Bali, Indonesia. She is currently a candidate doctorate in Linguistics at Udayana University and her main research focuses on Linguistic Translations.

I Nengah Sudipa is a Professor in Linguistics at Udayana University, Bali, Indonesia. He received his Master in Linguistics from Monash University in 1988 and his Doctorate in Linguistics from Udayana University, Bali, Indonesia in 2004. His research interests include a wide range of topics related to linguistics. He has supervised many theses and doctorate dissertations. He has participated in numerous national and international conferences and has written a lot of books and articles. 
I Nyoman Suparwa is a Professor in Linguistics at Udayana University, Denpasar, Bali, Indonesia. He is currently a vice Dean I at Faculty of Arts, Udayana University. He obtained his Master in Linguistics from Hasanuddin University, Indonesia in 1990 and his Doctorate in Linguistics from Udayana University in 2007. He has been a supervisor for numerous theses and doctorate dissertation. His research interests are phonology, psycholinguistics and language teaching. He has published many articles and book and actively participated in national and international conference and academic workshop.

Ida Ayu Made Puspani is a senior lecturer of English Department, Faculty of Arts at Udayana University, Bali, Indonesia. She obtained her Master in Applied Linguistics (Translation) in 2003 and her Doctorate in 2010 also in Applied Linguistics (Translation) in 2010. Both were received from Udayana University, Bali, Indonesia. Her research interests are translation and language teaching. Her publications include studies on translation (2013-2014), language teaching for young learners (2011) and court interpreting in Denpasar Court (2010). She has participated in many national and international conferences and workshops. 